\title{
DIVERSIFIKASI PRODUK KOLANG KALING PADA KELOMPOK USAHA BERIUK ANGENI DI DESA LEMBAH SARI KABUPATEN LOMBOK BARAT
}

\author{
Oleh \\ Lalu Yulendara ${ }^{1}$, I Putu Gede ${ }^{2}$ \& Syech Idrus ${ }^{3}$ \\ 1,2 dan 3 Dosen Sekolah Tingggi Pariwisata Mataram \\ Email: $\underline{{ }^{1} \text { laluyulendra@yahoo.co.id, }{ }^{2} \text { iputugede@gmail.com \& }{ }^{3} \text { sidroess@ gmail.com }}$
}

\begin{abstract}
Abstrak
Program Ipteks bagi Masyarakat di Desa Lembah Sari, Batu Layar Kabupaten Lombok Barat ditujukan untuk memberdayakan potensi yang ada pada kelompok usaha kolang kaling sebagai upaya untuk meningkatkan pendapatan masyarakat dan mendukung pengembangan destinasi wisata dan ekonomi kreatif dalam menyangga pembangunan pariwisata di kabupaten Lombok Barat mempunyai peran dan fungsi sangat strategis. Kegiatan Ipteks bagi Masyarakat pada produk kolang kaling ini lebih ditekankan pada penganekaragamannya (diversifikasi), menjadi beberapa produk, seperti; kerupuk kolang kaling, es kolang kaling, manisan dan dodol kolang kaling dengan maksud agar secara teknis proses pembuatan kolang kaling dalam diversifikasi produk olahan camilan dapat dilakukan dengan menggunakan alat bantu berteknologi kekinian, karena adanya temuan bahwa dalam proses pengolahan masih dilakukan secara tradisional dan kurang memperhatikan aspek hyginitas, demikian juga dalam pemasaran pun masih sederhana karena dijanjakan dilapak-lapak pasar dan sekolah. Metode yang digunakan untuk mencapai tujuan dari kegiatan Ipteks bagi Masyarakat ini, dilakukan dengan menggunakan langkah-langkah sebagai berikut; a) melakukan sosialisasi, b) menyusun rencana program, c) melak-sanakan program Ipteks bagi Masyarakat, d) melakukan monitoring, evaluasi dan menyusun laporan. Hasil kegiatan Ipteks bagi Masyarakat ini, antara lain; a) terlaksananya penyuluhan tentang pentingnya pemeliharaan tanaman Enao atau Aren sebagai bahan baku kolang kaling dan meyakinkan pengusaha/masyarakat bahwa camilan kolang kaling dapat dijadikan sebagai salah satu paket wisata kuliner dan wisata agro, b) terlaksananya pelatihan dalam proses pembuatan produk olahan camilan kolang kaling sehat dengan kemasan yang vareatif agar memiliki nilai jual kompetitif, c) terlaksananya kegiatan bimbingan untuk memperluas jangkauan pemasaran dengan memanfaat media sosial.
\end{abstract}

Kata-kata Kunci: Diversifikasi, Produk Enao dan Kolang Kaling.

\section{PENDAHULUAN}

Kolang kaling merupakan suatu produk olahan yang berasal dari pohon Aren atau Enao (Arenga pinnata Merr). Semua bagian tanaman Enao dapat diambil manfaatnya, mulai dari bagian-bagian fisik tanaman maupun dari hasil-hasil produksinya (Iswanto, 2009). Pohon aren kebanyakan tumbuh secara liar, baik di dataran rendah, lereng bukit, lembah, maupun pegunungan hingga ketinggian 1.400 meter dpl. Akar tanaman aren bisa mencapai kedalaman 6-8 meter, sangat potensial untuk menahan erosi dan air (Widyawati, 2011). Kolang- kaling http://ejurnal.binawakya.or.id/index.php/MBI

Open Journal Systems cukup populer di masyarakat Indonesia, terutama digunakan untuk membuat berbagai jenis makanan, dianiaranya untuk kolak, campuran es buah dan cendel. Pengolahan kolang kaling sebagai suatu produk kuliner oleh kelompok usaha Beriuk Angeni yang ada di Desa Lembah Sari di Kabupaten Lombok Barat baru sebatas dijadikan campuran es dan cendol, sedangkan air nira diproduksi hanya sebagai minuman segar atau sebagai bahan baku pengolahan gula yang telah banyak melibatkan dan memberikan manfaat kepada masyarakat di dalam dan sekitar hutan. Profil sasaran dalam kegiatan pengabdian ini adalah

Vol.13 No.1 Agustus 2018 
kelompok usaha Beriuk Angeni di Desa Lembah Sari, jaranyak dengan kampus Akademi Pariwisata Mataram yaitu sejauh $13,8 \mathrm{~km}$ bisa ditempuh dalam waktu 35 menit bisa ditempuh dalam waktu 26 menit melalui Jl. Raya Senggigi dan Jl. Raya Meninting, penduduk desa Lembah Sari bermatapencaharian petani dan sebagian besar masyarakat Lembah Sari berada pada areal hutan lindung yaitu seluas $200 \mathrm{Ha}$ yang keadaannya masih terpelihara dengan baik dan terdapat juga kebun Aren/Enao seluas $80 \mathrm{Ha}$ dengan produksi nira 1.000 liter/hari, secara geografis lokasi tempat tinggal masyarakat Lembah Sari berdekatan dengan kawasan hutan lindung Pusuk, berdasarkan Peraturan Daerah No. 9 tahun 1989 kawasan Pusuk ditetapkan sebagai kawasan wisata hutan lindung, skaligus sebagai destinasi/daerah wisata andalan di Kabupaten Lombok Barat.

Jumlah pengolah buah kolang kaling yang ada di desa Lembah Sari begitu banyak tersebar diareal kebun-kebun rakyat dengan jarak yang cukup jauh satu dengan yang lainnya dan pengelolaanya lebih dominan dilakukan secara individu/perorangan dan hanya di Dusun Pusuk pengolahannya dilakukan secara berkelompok. Kelompok Beriuk Angeni yang menjadi mitra berada di Dusun Pusuk. Jumlah pengolah buah kolang kaling di wilayah desa Lembah Sari Kecamatan Batu Layar Kaupaten Lombok Barat dapat dilihat pada Tabel 1.
Tabel 1. Data Pengolah Buah Kolang Kaling di Desa Lembah Sari Kecamatan Batu Layar Kabupaten Lombok Barat

\begin{tabular}{|c|c|c|c|}
\hline \multirow[t]{2}{*}{ No. } & \multirow[t]{2}{*}{ Nama Dusun } & \multicolumn{2}{|c|}{$\begin{array}{l}\text { Jumlah Pengolah Buah Kolang } \\
\text { Kaling }\end{array}$} \\
\hline & & Kelompok & Perorangan \\
\hline 1 & Bengkaung Lauk & - & - \\
\hline 2 & Bengkaung Tengah & - & 6 \\
\hline 3 & Bengkaung Daye & - & 14 \\
\hline 4 & Bunian & - & 32 \\
\hline 5 & Sraye & - & 7 \\
\hline 6 & Pelolat & - & 76 \\
\hline 7 & Bunut Boyot & - & 83 \\
\hline 8 & Lendang $\operatorname{Re}$ & - & 5 \\
\hline 9 & Sidemen Lauk & - & 93 \\
\hline 10 & Sidemen Daye & - & 75 \\
\hline 11 & Batu Penyu & - & 35 \\
\hline 12 & Kedondong Atas & - & 80 \\
\hline 13 & Kedondong Bawah & - & 49 \\
\hline 14 & Pusuk & 2 & 57 \\
\hline \multicolumn{2}{|c|}{ Jumlah } & 2 & 612 \\
\hline
\end{tabular}

Sumber : Profil Desa Lembah Sari Kecamatan Batu Layar (2015).

Berdasarkan data statistik di kantor Desa Batu Layar dan Desa Lembah Sari, pendidikan pengolah buah kolang kaling sebagian besar Sekolah Dasar (SD), tentunya pemahaman tentang pentingya hygien dan sanitasi rata-rata rendah, terlebih lagi menciptakan variasi produk dan pemasaran masih sangat tergantung kepada pihak ketiga (penadah). Keberadaan pengolah buah kolang kaling di Dusun Pusuk Desa Lembah Sari Kecamatan Batu Layar memberikan dampak yang bergitu besar terhadap kegiatan ekonomi kerakyatan, lingkungan alam terutama untuk mempertahankan fungsi hutan hasil produksi, menjaga resapan air, terpeliharanya komoditas tumbuhan, disisi lain keberadaan pengolah buah kolang kaling yang berada dekat kawasan hutan lindung khususnya Pusuk memberikan dampak yang sangat positif bagi pengembangan destinasi wisata jika dikaitkan dengan aktivitas dan proses pengolahan dapat ditawarkan sebagai salah bentuk wisata kuliner yang menarik kepada wisatawan terutama dalam memperkaya paket wisata yang telah ada. Aktivitas wisata yang dikemas dengan baik dalam satu paket wisata kuliner maka secara tidak langsung pengolah buah kolang kaling, baik dalm suatu kelompok maupun http://ejurnal.binawakya.or.id/index.php/MBI 
perorang dan masyarakat setempat dapat merasakan dampak ekonominya.

Buah kolang kaling memiliki kandungan serat dan mineral dalam setiap 100 gram kolang-kaling yaitu energi 27 kkal, protein 0,4 gram, lemak 0,2 gram, karbohidrat 6 gram, serat 1,6 gram, kalsium $91 \mathrm{mg}$, fosfor $243 \mathrm{mg}$ dan zat besi $0,5 \mathrm{mg}$ serta kadar air mencapai $94 \%$. Kolang kaling juga mengandung vitamin $\mathrm{A}, \mathrm{B}$ dan $\mathrm{C}$ serta memiliki kandungan kalsium, besi dan fosfor yang berkhasiat untuk menjaga tubuh agar tetap bugar dan sehat (Julianto, 2014). Kolang kaling dapat memiliki nilai ekonomi tinggi apabila produknya diolah dengan penganganekaragaman (diversifikasi). Secara teknis proses pembuatan kolang kaling sebagai produk olahan camilan masih dilakukan secara tradisional dan pada hal jika dikelola dengan baik produk olahan kolalang kaling memilki potensi pasar cukup bagus, karena dapat dijadikan sebagai bahan dasar pembuatan aneka olahan makanan dan minuman.

\section{PERMASALAHAN MITRA}

Setelah dilakukan diskusi mendalam dengan pengolah buah kolang kaling, khususnya anggota kelompok Beriuk Angeni yang ada di Dusun Pusuk Desa Lembah Sari Kecamatan Batu Layar, maka dapat diidentifikasi beberapa permasalahan yang dihadapi oleh pengolah buah kolang kaling saat ini, antara lain:

1. Produksi belum berpariasi.

2. Pemasaran masih sangat terbatas.

3. Proses pengolahan kurang hyginitas.

Bila dilihat dari aspek produksi, produksi yang terbatas itu disebabkan oleh karena produksi yang dihasilkan belum berpariasi baru sebatas es dan cendol. Jika dilihat dari aspek pemasaran, pemasaran sangat terbatas itu, karena sebagian besar pemasaran dilakukan dari mulut kemulut, dijanjakan dilapak-lapak pasar dan sekolah. Selanjutnya proses pengolahan masih dilakukan secara tradisional dan kurang memperhatikan aspek hyginitas. Dalam http://ejurnal.binawakya.or.id/index.php/MBI kegiatan Iptek bagi Masyarakat ini, masalah yang disepakai untuk ditangani adalah masalah pertama, yakni produksi yang dihasilkan belum berpariasi, karena produksinya masih terbatas pada campuran es dan cendol kolang kaling). Pemilihan masalah dalam kegiatan ini sangat rasional, karena itu diperlukan adanya penganekaragaman (diservikasi) produk buah kolang kaling dengan cara memberi pelatihan pada anggota kelompok Beriuk Angeni sebagai pengolah buah kolang kaling, selain itu, tim pelaksana pengabdian memberikan motivasi bagi yang mengolahnya secara perorangan untuk dilakukan lebih baik berkelompok, karena dengan berkelompok dapat diukur standar kerja, baik proses maupun hasilnya.

\section{TARGET DAN LUARAN KARYA UTAMA}

Berdasar pada permasalahan yang ada serta rencana kegiatan yang akan dilaksanakan sebagai solusi dalam mengatasi permasalahan yang dialami mitra kelompok usaha kolang kaling Beriuk Angeni dalam diversifikasi produk di Dusun, Pusuk Desa lembah sarri, Kecamatan Batulayar Kabupaten Lombok Barat dengan target luaran yang dihasilkan berupa produk camilan yang bisa berkembang menjadi wisata kuliner dan wisata agro. Adapun luaran yang dihasilkan dari kegiatan ini adalah sebagai berikut :

1. Membuat produk camilan, seperti krupuk, permen/manisan dan dodol kolang kaling.

2. Melakukan pembimbingan untuk memperluas bererdarnya produk atau memasarkan dengan jangkau lebih luas menggunakan/memanfaat media sosial.

3. Melakukan pelatihan produksi yang hygienis dan efisien.

\section{METODE PELAKSANAAN}

Berdasarkan permasalahan, target dan keluaran dari kegiatan ini, metode yang digunakan untuk menyelesaikan masalah yaitu dengan menggunakan pemberdayaan kelompok dengan mengutamakan partisipatif

Vol.13 No.1 Agustus 2018 
dari seluruh anggota kelompok mitra untuk mengikuti pelatihan dan bimbingan seperti yang telah direncanakan sebelumnya. Unsur utama dalam proses itu adalah penguatan kapasitas anggota dalam kelompok Beriuk Angeni dan memberikan akses penguatan manajemen usaha melalui pengembangan produk dengan melalui pengaanekaragaman (diversifikasi) dengan memberikan pelatihan keterampilan pengolahannya dari bahan baku buah kolang kaling menjadi makanan yang berpariasi berkualitas tinggi, dan melakukan pelatihan cara proses produksi serta pengemasan yang menarik, hygienis dan efisien, pembimbingan mengenai pemasaran dengan memanfaatkan media sosial yang ada.

Langkah-langkah pelaksanaan kegiatan Iptek bagi Masyarakat pada kelompok usaha Beriuk Angeni, sebagai berikut: Sosialisasi, Penyusunan Rencana Program (TOR), Pelaksanaan Program dan Monitoring, Evaluasi, dan Pelaporan.

1. Sosialisasi

Tujuan untuk memperkenalkan program kegiatan pengabdian kepada masyarakat tentang tehnis dan tata cara pengolahan buah kolang kaling bagi mitra untuk pengembangan produk dengan melalui pengaanekaragaman (diversifikasi). Gambar sosialisasi dapat dilihat pada Gambar 1.

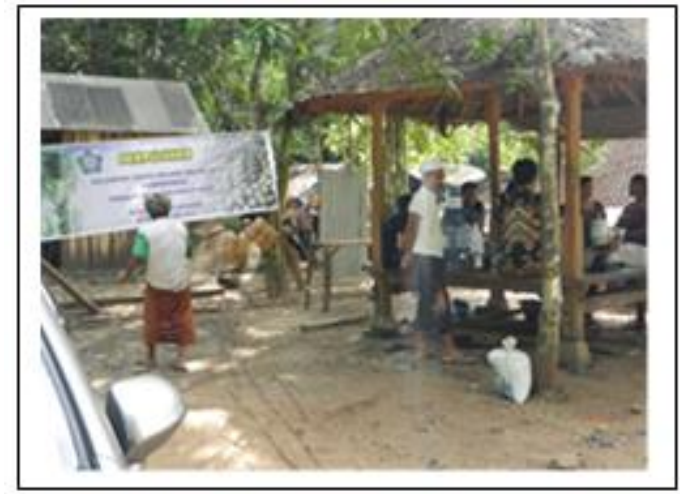

Gambar 1. Sosialisasi Program IbM

2. Penyusunan Rencana Program

Tujuan ; a. menjaring informasi atau data tentang potensi, masalah yang ada pada mitra terutama yang berkaitan dengan rencana pengembangan pemanfaatan buah kolanng kaling, diversivikasi produk buah kolang kaling. b. menyusun rencana program Iptek bagi Masyarakat.

3. Pelaksanaan Program dan Monitoring

a. Pelaksanaan Program

Tujuan ; a. pelatihan dan bimbingan pengembangan diversivikasi produk olahan buah kolang kaling (dapat dilihat pada Gambar 2); b. pelatihan dan bimbingan pengembangan teknologi produksi yang hygienis dan efisien; c. pelatihan dan bimbingan pemanfaatan media sosial untuk memperluas pasar.

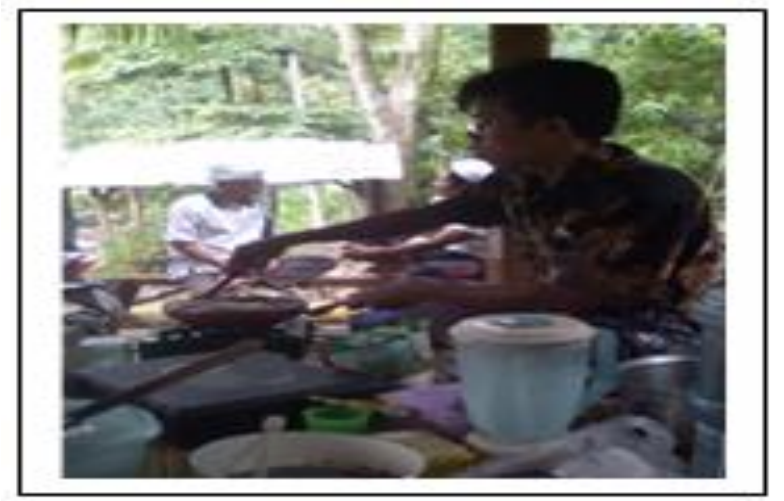

Gambar 2. Demontrasi Diversifikasi Produk Buah Kolang Kaling

b. Monitoring

Tujuan ; mengetahui kesesuaian antara rencana program dan realisasi atau pencapaian tujuan dari setiap langkah kegiatan.

4. Evaluasi

Tujuan; mengetahui tingkat pencapaian atau keberhasilan program kegiatan pengabdian yang telah direncanakan secara keseluruhan.

5. Pelaporan

Tujuan; tersusunnya laporan kegiatan akhir dari kegiatan IbM untuk kelompok usaha Beriuk Angeni yang ada di Desa Lembah Sari Kecamatan Batu Layar Kabupaten Lombok Barat.

\section{HASIL DAN PEMBAHASAN}

Hasil dan pembahasan yang dicapai dalam kegiatan ini adalah menggambarkan 
bahwa sejauhmana pencapaian yang telah diperoleh dari semua aktipitas yang dilakukan, antara lain:

\section{Sosialisasi}

1. Kegiatan ; a. tim pelaksana datang ke Dusun Pusuk Desa Lembah Sari Kecamatan Batu Layar sebagai lokasi pelaksanaan IbM; b. memperkenalkan diri sebagai tim pada perangkat dusun dan desa, tokoh masyarakat, kelompok usaha kelompok Beriuk Angeni pihak lain di lokasi yang dianggap perlu; c. memberikan informasi awal tentang kegiatan program Iptek bagi Masyarakat.

2. Pada saat proses sosialisasi yang berlangsung, anggota kelompok Beriuk Angeni maupun masyarakat yang hadir diberikan kesempatan untuk bertanya.

\section{Penyusunan rencana program}

1. Kegiatan; a. menggunakan atau memanfaatkan data dan informasi yang sudah diperoleh ketika melakukan observasi ke Dusun Pusuk Desa Lembah Sari Kecamatan Batu Layar sebagai awal permulaan untuk mengidentifikasi masalah; b. menggali informasi sebanyak-banyaknya melalui ketua kelompok, anggota Beriuk Angeni, tokoh masyarakat dan sumber lainnya mengenai masalah pengolahan buah kolang kaling; c. menyusun program Iptek bagi Masyarakat; dan d. melakukan Focus Group Discution (FGD).

2. Pada saat penyusunan rencana program khususnya FGD bahwa:

a. Kelompok Beriuk Angeni menyambut baik program pengabdian ini.

b. Program ini dapat menjadi solusi masalah yang berhubungan dengan produksi.

c. Bersedia dengan suka rela mengikuti kegiatan pengabdian ini.

d. Dapat menambah penghasilan dari pengolahan buah kolang kaling beranekaragam.

http://ejurnal.binawakya.or.id/index.php/MBI
Pelaksanaan program dan monitoring Pelaksanaan program

1. Kegiatan; a. menjelaskan pentingnya mengolah buah kolang kaling menjadi penganekaragam (diversifikasi) produk; $b$. melakukan pelatihan ketrampilan membuat produk olahan dari buah kolang kaling menjadi setup pisang kolang kaling, kolak ubi kolang kaling, manisan kolang kaling, sop buah kolang kaling, dodol kolang kaling dan kerupuk kolang kaling; c. melakukan pelatihan ketrampilan prosesing penyimpanan, packing dan delivery; $\mathrm{d}$. melakukan pelatihan proses produksi yang hygienis dan efisien; e. melakukan pembimbingan dalam rangka memanfaatkan media sosial untuk pelaksanaan pemasaran (marketing).

2. Pengolahan buah kolang kaling

Beberapa penganegaraman (diversifikasi) pengolahan buah kolang kaling yang dilatihkan kepada kelompok Beriuk Angeni, seperti membuat; setup pisang kolang kaling, kolak ubi kolang kaling, manisan kolang kaling, sop buah kolang kaling, dodol kolang kaling dan kerupuk kolang kaling.

a. Setup pisang kolang kaling

Bahan-bahan:

8 buah pisang kepok, potong menjadi beberapa bagian

125 gr gula pasir

50 gr gula merah

2 buah kayu manis

kolang kaling

5 butir cengkeh

1 buah sereh (optional)

1 liter air

Cara pengolahan sebagai berikut :

Didihkan air, masukkan gula, cengkeh, kayu manis, sereh, kemudian masukkan kolang kaling disisihkan sekali lagi. Masukan pisang dan masak sampai matang. Sajikan hangat atau dingin.

b. Kolak ubi dan kolang kaling

Bahan-bahan

500 gr kolang kaling

Vol.13 No.1 Agustus 2018 
500 gr ubi

250 gr gula merah

5 lembar daun pandan

2 satu sendok makan vanili

garam secukupnya

1 liter air

2 bks santan instan

Cara pengolahan sebagai berikut :

Gula merah diiris lalu masukan ke dalam panci bersama vanili dan daun pandan. Selanjutnya ditambah air dan direbus sampai gula larut. Kemudian kolang kaling dimasukkan dan terakhir ubi. Jika ubi dan kolang kaling sudah mulai lunak maka diberi santan. Sambil diaduk terus agar santan tidak pecah.

c. Manisan kolang kaling

Bahan-bahan

$1 / 2 \mathrm{~kg}$ kolang kaling

$750 \mathrm{ml}$ air cucian beras

250 gr gula pasir (sesuai selera)

2-3 sdm pasta pandan

1 kayu manis

2 daun pandan

3 daun jeruk

garam secukupnya

Cara pengolahan sebagai berikut :

Kolang kaling dicuci lalu rendam dengan air cucian beras 25-30 menit, setelah dicuci lagi hingga bersih. Kemudian air $500 \mathrm{ml}$ direbus bersama gula, pasta pandan, daun pandan, daun jeruk, garam dan kayu manis. Jika gula sudah larut masukkan kolang kaling, lalu aduk hingga air meresap dan agak menyusut sedikit. Angkat dan setelah dingin masukkan ke dalam kulkas. Siap disajikan.

d. Sop Buah kolang kaling

Bahan-bahan

1 buah apel

1 buah naga

500 gr kolang kaling

sirup (sesuai selera)

susu cair

batu es

Cara pengolahan sebagai berikut :

Vol.13 No.1 Agustus 2018
Potong buah apel dan buah naga lalu campur kolang kaling dan buah yang sudah dipotong dalam satu wadah. Kemudian sirup secukupnya, susu dan batu es. Siap disajikan.

e. Dodol Kolang kaling

Bahan-Bahan

Kolang Kaling $500 \mathrm{Gr}$

Gula Pasir $250 \mathrm{Gr}$

Air $250 \mathrm{Cc}$

Garam 1 Sdt

Tepung Ketang 75 Gr

Vanili Secukupnya

Cara pengolahan sebagai berikut :

Kolang kaling di bersihkan di cuci sampai bersih setelah itu diblender sampai halus, masukan kolang kaling yang sudah halus tersebut tambahkn gula pasir, garam, tepung ketan, dan vanilla serta panaskan sambil di aduk jangan sampai berkerak kurang lebih 60 menit atau sampai kolang kalis setelah itu turunkan, dinginkan dan siap dikemas.

Dengan melibatkan petugas penyuluh pertanian dan peternakan lapangan untuk menyapaikan tehnik perawatan itik petelur pra bertelur dan sesudah bertelur kepada kedua kelompok peternak itik petelur. Semua peserta menyambut baik, karena banyak mendapat masukkan yang positif dan menambah pengetahuan.

f. Kerupuk Kolang - Kaling

Bahan-bahan

500 gr kolang kaling segar

500 gr tapioca

$400 \mathrm{cc}$ air

2 sdt garam

4 siung bawang putih

1 sdt garam

500 cc minyak goreng

Jika dbutuhkan bisa di tambahkan dengan masako

Cara pengolahan sebagai berikut :

Kolang kaling di giling sampai halus menggunakan blender, panaskan panic atau wajan stainless stell atau panic stainless steel masukkan kolangkaling http://ejurnal.binawakya.or.id/index.php/MBI 
yang sudah di haluskan, masukkan tepung tapioca, garam, bawang putih, aduk rata hingga matang panaskan kurang lebih 5 menit. Setelah itu masukkan dalam plastik es kemudian di kukus 20 menit hingga matang, selanjutnya matang kolang kaling di dinginkan lalu diiris tipis, jemur hingga kering, terkahir digoreng dengan panas sedang.
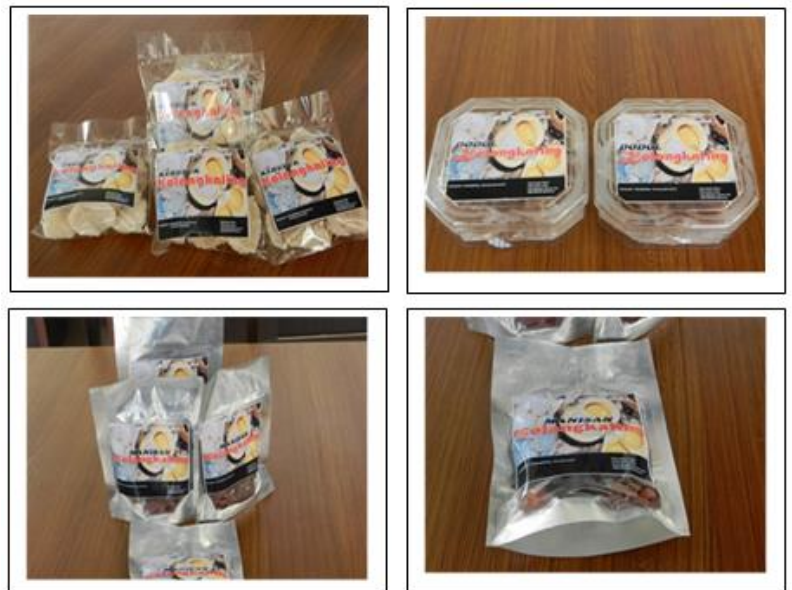

Gambar 3. Hasil Diversifikasi Produk Buah Kolang Kaling

3. Pelatihan prosesing penyimpanan, packing dan delivery

Prosesing penyimpanan, packing dan delivery dilatihakan kepada mitra berbarengan dengan proses pelatihan pengolahan buah kolang kaling menjadi anekaragam produk, karena berbagai macam karekteristik produk yang dihasilkan dari buah kolang kaling, tentunya cara dan model penyimpanan dan packingnya pun berbeda, sedangkan deliverynya sama.

4. Pelatihan proses produksi yang hygienis dan efisien

Pelatihan proses produksi yang hygienis dan efisien yang diberikan kepada mitra bersamaan dengan proses pelatihan pengolahan buah kolang kaling menjadi anekaragam produk, dengan karekteristik yang berbeda tentu hygienis dan efisiensi yang berbeda pula.
5. Pembimbingan

dalam

rangka memanfaatkan media sosial untuk pelaksanaan pemasaran (marketing), memberikan informasi dan motivasi serta melakukan pembimbingan bagaimana memnafaat media sosial sebagai alat yang jitu untuk mempromosikan produk yang dihasilkan dengan harapan lebih banyak konsumen mengetahui dapat melakukan pemesanan dimana dan kapan pun.

\section{Monitoring}

1. Kegiatan : a. melakukan monitoring terhadap pelaksanaan program; b. melakukan identifikasi hambatan pencapaian target; c. menyusun kegiatan perbaikan pelaksanaan program pengabdian masyarakat.

2. Pada kegiatan monitoring menunjukan: a. mitra sepenuhnya melaksanakan program yang telah ditetapkan oleh tim pelaksana pengabdian termasuk meng aplikasikannya dalam aktivitas sehari hari; b. ditemukan beberapa hambatan dan dilakukan identifikasi seperti perbedaan daya serap setiap anggota kelompok; c. keterbatasan peralatan pendukung kegiatan mitra cukup menggangu program; dan d. hambatan komunikasi tim dengan mitra pendam-ping menjadi hal yang perlu pertimbangan.

\section{Evaluasi}

1. Kegiatan: a. mencermati kembali aspekaspek pengabdian dalam pelaksanaan pengolahan buah kolang kaling menjadi anekaragam (diversifikasi) produk; b. menentukan tingkat pen-capaian tujuan secara jujur, merumuskannya dalam bentuk kuantitatif (persentase), serta data lain.

2. Pada kegiatan evaluasi bahwa : a. tim pelaksana pengabdian melakukan peninjauan dan penguatan terhadap kendala dan kekurangan program untuk dapat melanjutkan pada kegiatan berikut agar kegiatan ini dapat diteruskan; b. keberadaan kelompok usaha kolang kaling (Beriuk Angeni) dalam IbM ini, dioptimalkan sebagai pelaku utama yang diberdayakan 
untuk meningkatkan usaha dalam rangka meningkatkan pendapatan.

\section{KESIMPULAN DAN REKOMENDASI}

Bahwa penganekaragaman (diversifikasi) produ bagi usaha olahan buah kolang kaling meru-pakan suatu bentuk kegiatan pengabdian pada masyarakat yang merupakan suatu kegiatan yang dapat menumbuhkan kesadaran bahwa pohon aren perlu untuk dilestarikan dan buahnya jika diolah dengan berbagai macam cara akan memberikan manfaat dan dapat meningkatkan pendapat bagi kelompok usaha buah kolang kaling yang ada di Dusun Pusuk Desa Lembah SariKecamatan Batu Layar Kabupaten Lombok Barat. Untuk efektifnya program ini dilakukan dengan sosialisasi FGD untuk memperkuat mitra dan masyarakat yang ada disekitar hutan lindung.

\section{Saran}

Kegiatan IbM yang dilaksanakan bagi kelompok Beriuk Angeni pengolah buah kolang kaling menjadi berbagai macam olahan memiliki manfaat yang banyak, terutama dapat menjaga kelestarian pohon Aren/Enao yang ada di wilayahnya dan yang paling penting dapat mening-katkan pendapatan, oleh karena itu sangat direkomendasikan program ini untuk dapat ditindak lanjuti, mengingat di Desa Lembah Sari sebagian besar pengolah buah kolang kaling masih bersifat perorangan, untuk itu, diharapkan pengolah buah kolang kaling perorangan dapat membetuk kelompok, karena dengan berkelompok proses pembuatan, hyginitas, penyimpanan, packing dan delivery dapat dilalukan sesuai distandar yang telah ditentukan.

\section{DAFTAR PUSTAKA}

[1] Iswanto, A. H. 2009. Aren (Arenga pinnata). Karya Tulis. Universitas Sumatera Utara. Medan.

[2] Julianto. 2014. Khasiat tersembunyi kolang kaling. Jakarta: Sinar Tani.
[3] Widyawati, N., 2011. Sukses Investasi Masa Depan dengan Bertanam Pohon Aren. Yogyakarta: Lily Publisher.

[4] Purwati dan Tutik Nugrahini. 2018. Pemanfaatan Buah Kolang Kaling Dari Hasil Perkebunan Sebagai Pangan Fungsional. Jurnal Abdimas Mahakam. Vol.2 No.1, pp. 2549-2755. 